\title{
PENGARUH CHLOROQUINE TERHADAP INTERLEUKIN-1 $\beta$, AKTIVASI CASPASE-1 DAN SURVIVAL RATE PADA TIKUS MODEL SEPSIS
}

\author{
EFFECT OF CHLOROQUINE ON INTERLEUKIN-1ß, CASPASE-1 ACTIVATION AND \\ SURVIVAL RATE ON MOUSE SEPSIS MODEL
}

\author{
Aryo Suseno. Tatar Sumandjar. H M Bambang Purwanto. \\ Bagian Ilmu Penyakit Dalam RS Dr.Moewardi - FK Universitas Sebelas Maret Surakarta. \\ Korepondensi: Aryo Suseno: aryosuseno23@gmail.com
}

\begin{abstract}
ABSTRAK
Sepsis masih merupakan salah satu penyebab kematian tertinggi di ruang rawat intensif. Mekanisme sepsis belum diketahui secara penuh. Perlunya metode-metode baru dalam penanganan sepsis. Penelitian-penelitian baru menemukan adanya peran dari Nod-like Receptor dan inflammasome. Chloroquine menunjukkan hasil yang cukup menjanjikan. Penelitian ini bertujuan untuk mengetahui pengaruh qloroquin terhadap interleukin-1 $\beta$, aktivasi caspase-1 dan survival rate pada tikus model sepsis. Penelitian adalah eksperimen hewan coba (Rattus norvegicus) yang disepsiskan dengan Cecal Ligation and Puncture (CLP). Sampel 52 tikus, dibagi menjadi 2 kelompok; Kelompok 1 untuk IL-1 $\beta$ dan kelompok 2 aktivasi Caspase-1. Tiap kelompok dibagi 3 sub kelompok; kontrol tanpa $\mathrm{CLP}+$ placebo $(\mathrm{NaCl} 0.9 \% 2 \mathrm{ml})$, perlakuan dengan $\mathrm{CLP}+$ placebo, dan kelompok terapi dengan CLP + Chloroquine (CHQ) 50mg/Kg BB personde. Terapi dan placebo diberikan 24, 48 dan 72 Jam setelah CLP. Tikus mati dan moribund dicatat sebagai mortalitas. Pada hari ke 6, tikus yang hidup diambil darahnya dan dikorbankan dengan dislokasi servikal. Kadar IL-1 $\beta$ dengan ELISA pada serum, Aktivasi Caspase-1 dengan Flowcytometry dengan pewarnaan FLICA 660 pada Peripheral Blood Mono-Nuclear Cells (PBMC) dan Whole Blood (WB). Analisis dengan SPSS 22. Beda rerata masing-masing subkelompok dianalisa dengan ANOVA bila distribusi normal dan atau uji Kruskal-Wallis dilanjutkan dengan Mann-Whitney.Hasil penelitian menunjukkan tidak adanya perbedaan survival rate yang bermakna antar sub-kelompok dan antar kelompok (mean 52 vs 62, CI: (-37.32) - 27.98, $P=0.767)$. Didapatkan rerata kadar $I L-1 \beta$ yang lebih rendah pada kelompok terapi dibanding kelompok perlakuan (mean 0.08975 vs 0.09680 CI: (-0.024) - 0.0097, $P=0,376)$, namun tidak bermakna secara statistik. Rerata tingkat aktivasi Caspase-1 pada PBMC (mean 9,46 vs 15.04 CI: (-6.72) - 24.82, P=0.865) dan WB (mean 2,99 vs 10,99 CI: (-5.303) - 5.844, $P=0.478$ ) lebih rendah pada kelompok terapi dibanding perlakuan walaupun tidak bermakna secara statistik. Penelitian ini menunjukkan bahwa penghambatan kadar inflamasi tidak berhubungan langsung dengan survival rate. Mekanisme anti-inflamasi Chloroquine, salah satunya, tampak melewati jalur inflammasome.
\end{abstract}

Kata kunci: Sepsis, Chloroquine, Inflammasome, Caspase-1, IL-1 , Survival rate.

\section{ABSTRACT}

Sepsis is still one of the main mortality cause in intensive care. The sepsis mechanism is still not fully undertood. The need to develop new method and strategies is imperative. Recent studies has higlighted the role of Nod-like Receptor and inflammmasome. Chloroquine has show promising results in animal studies. This aimed of this study is determine the effect of qloroquin toward interleukin-1 $\beta$, activation of caspase-1 and survival rate in mice model of sepsis. This is an animal base experimental study (Rattus norvegicus) which induce sepsis by Cecal Ligation and Puncture (CLP) method. Total of 52 mouse use as sample, divided into 2 groups; IL-1 group and Caspase-1 activation group. Each group are further divided to 3 sub-group; Control without CLP + placebo (NaCl $0.9 \% 2 \mathrm{ml})$, intervention group with CLP + placebo, and treatment group with CLP + Chloroquine (CHQ) $50 \mathrm{mg} /$ $\mathrm{Kg}$ BB orally administer. The treatment or placebo are given on 24, 48 and 72 hours after CLP. Dead mouse or in moribund condition are noted as mortality. On the $6^{\text {th }}$ day, all surviving animals are bled and euthenised by cervical dislocation. IL-1 $\beta$ serum levels are measured by ELISA, Caspase-1 activation are analyzed by Flowcytometry with FLICA 660 staining on Peripheral Blood Mono-Nuclear Cells (PBMC) and Whole Blood (WB). Statistical analysis are done by SPSS 22. Difference of mean between sub-group is analyzed by ANOVA in case of normally distributed data or with Kruskal-Wallis continue by the Mann-Whitney test. This study do not show any difference 
in survival rate between groups and sub-groups. (mean 52 vs 62, CI: (-37.32) - 27.98, P=0.767). The mean of IL$1 \beta$ level are lower in the treatment group compares to the intervention group, although not statistically significant (mean 0.08975 vs $0.09680 \mathrm{CI}:(-0.024)-0.0097, P=0,376)$. The average of Caspase-1 activation are also lower in the treament PBMC sub-group (mean 9,46 vs $15.04 \mathrm{CI}:(-6.72)-24.82, P=0.865)$ as well as in the WB (mean 2,99 vs 10,99 CI: (-5.303) - 5.844, P=0.478) but no statistical significance is detected. This study shows that the inhibition of inflammation is not directly coresponds to survival rate. One of the anti-inflammatory mechanism of Chloroquine presumably through inflammasome pathway.

Keywords: Sepsis, Chloroquine, Inflammasome, Caspase-1, IL-1 $\beta$, Survival rate.

\section{PENDAHULUAN}

Sepsis adalah adanya suatu infeksi (kemungkinan atau terbukti) bersama dengan manifestasi sistemik dari infeksi (Dellinger et al, 2012). Patofisiologi sepsis yang dianut sampai saat ini adalah adanya kondisi hiper-inflamasi yang terpicu oleh adanya infeksi yang mana akan merusak tubuh penderita (Hermawan, 2008; Hermawan, 2011). Walaupun dengan kemajuan ilmu kedokteran yang pesat para ahli telah dapat banyak mengungkap misteri dari sepsis, namun sepsis masih merupakan masalah dunia medis yang pelik. Pada tahun 2000 di Amerika Serikat, sepsis meningkat 9\% setiap tahunnya, mengenai 240 orang tiap 100.000 penduduk. Sepsis menjadi penyebab kedua terbanyak penyebab admisi perawatan intensif non kegawatan kardiovaskular, $10-14 \%$ penyebab admisi ICU dari total dan merupakan penyebab kematian tertinggi kesepuluh di negara-negara maju, membunuh 200.000 orang di amerika dan 37.000 orang di Inggris tiap tahunnya dengan tingkat mortalitas mencapai 2850\% (Van der Poll \& Opal, 2008).

Penelitian-penelitan baru mengungkapkan beberapa target terapi baru pada sepsis. Salah satunya melewati jalur aktivasi Inflammasome NOD-like receptor (NLR). NLR adalah salah satu jenis dari Pattern Recognition Receptor (PRR). PRR adalah komponen utama dari sistem imun bawaan (Innate) yang mengenali sinyal-sinyal bahaya, seperti infeksi bakteri, dan kemudian memicu respon kekebalan tubuh. PRR mengenali pola-pola khusus dari mikroorgnisme yang terdapat pada patogen yang disebut sebagai Pathogen-associted molecular pattern (PAMP) seperti Lipopolisakarida (LPS), Peptidoglikan, Lipopeptida (komponen dari banyak patogen), Asam Lipoteikoik (dinding sel bakteri gram positif), Flagelin (faktor mobilitas bakteri), dan DNA bakteri (Bianchi, 2007; Kawai \& Akira, 2010). PRR juga dapat mengenali sinyal bahaya endogen, yang disebut alarmins atau Dangerassociated molecular pattern (DAMP), yang dilepaskan pada saat tubuh inang mengalami stres inflamasi (misalnya, luka bakar, trauma, dan nekrosis jaringan), yang kemudian memperingatkan sistem kekebalan tubuh terhadap bahaya yang akan datang (Kawai \& Akira, 2011).

NLR berdasarkan letaknya yang berada di sitoplasma sel, bertugas untuk mengenali materimateri PAMP atau DAMP yang masuk ke dalam sel. Ini termasuk DNA dan RNA virus, LPS yang berhasil masuk ke dalam sel, produksi sitokin proinflamasi endogen sel, komponen bakteri gram negatif yang masuk dalam sel via jalur sekretori bakteri tipe 3 dan tipe 4 , dan sebagainya. PRR sitosilik ini dibagi menjadi dua golongan besar berdasarkan susunan N-terminalnya. NLRP yang mengandung domain Pyrin dan NLRC yang mengandung domain CARD. Dari kedua golongan besar tersebut, telah diidentifikasi beberapa NLR, akan tetapi yang sampai saat ini yang paling banyak dipelajari adalah NLRP-3 (Bournefiend \& Hornung, 2013). NLR pada dasarnya akan mengaktifkan protein pro Caspase-1 yang bertugas merubah bentuk inaktif pro $I L-1 \beta$ dan pro $I L-18$ menjadi bentuk aktif $I L-1 \beta$ dan $I L-18$ yang dapat disekresikan keluar sel untuk mengamplifikasi reaksi inflamasi. NLR juga dapat menginduksi Pyroptosis di mana akan menyebabkan kematian sel dan terlepasnya berbagai mediator inflamasi. Dari beberapa NLR tersebut di atas, yang paling banyak dipelajari adalah NLRP3 dikarenakan keunikannya karena dapat distimulasi oleh berbagai macam DAMP dan PAMP atau bahkan disregulasi dari lingkungan intrasel seperti influks calsium dan efluks kalium (Bournefield \& Hornung, 2013; Wen et al, 2013).

Chloroquin atau Hydroxy-Chloroquine merupakan obat anti-malaria yang mempunyai efek anti-inflamasi dan telah digunakan sebagai agen DMARD. Chloroquine telah diketahui 
mampu menghambat produksi $H M G B-1$ pada mencit yang diinduksi oleh LPS. Beberapa penelitian menunjukkan bahwa Chloroquine dapat mengahambat produksi $T N F-\alpha, I L-6$, dan IL-1. Pada satu penelitian, produksi $H M G B-1$ dihambat produksinya terlepas dari aktivasi TLR4 yang merupakan PRR utama yang mengenali LPS di membran sel dan telah dikaitkan dengan penghambatan pembentukan inflammasome (Lamkanfi et al, 2010). Dikarenakan HMGB1 merupakan mediator fase lambat yang mana biasanya dikeluarkan setelah nekrosis sel, hal ini menimbulkan pertanyaan apakah efek antiinflamasi Chloroquine berada pada penghambatan sistem inflammasome atau dikarenakan penghambatan kematian sel.

Penelitian ini bertujuan untuk mengetahui pengaruh Chloroquine pada kadar IL-1 $\beta$, aktivasi Caspase-1 dan survival rate pada sepsis.

\section{METODE PENELITIAN}

Penelitian ini merupakan penelitian eksperimental berbasis hewan, dengan memberi perlakuan terhadap tikus Rattus norvegicus sebagai hewan coba di laboratorium. Dipilihnya jenis penelitian ini karena dapat menghasilkan data dengan validitas yang tinggi dikarenakan perlakuan dan kondisi percobaan dapat diatur oleh peneliti sehingga dapat mengurangi bias-bias yang mungkin menggangu analisa (Zainuddin, 1999). Penelitian dilakukan di Laboratorium Biomedik, Laboratorium Histologi dan Balai Besar Penelitian dan Pengembangan Tanaman Obat dan Obat Tradisional (B2P2TOOT), Kementerian Kesehatan, Tawangmangu.

Subjek penelitian adalah tikus putih jantan (Rattus norvegicus) dewasa dengan berat badan 150-200 gram dan berumur 3-4 bulan. Bahan makanan tikus putih yang digunakan adalah BR I. Pada penelitian ini diadakan dua kelompok yang mana pada kelompok pertama untuk mengukur kadar IL-1 Beta plasma dan kelompok kedua untuk mengukur aktivasi Caspase-1. Kedua kelompok kemudian dibagi lagi menjadi 3 sub-kelompok; 1) Kelompok perlakuan yang dilakukan prosedur CLP yang diberi plasebo $\mathrm{NaCl}$ 0,9\%, Kelompok terapi yang dilakukan prosedur CLP yang diberi perlakuan dengan Chloroquine oral, dan kelompok Kontrol adalah kelompok tikus tanpa prosedur CLP dan diberi $\mathrm{NaCl}$ 0,9\% peroral, disebut " $\mathrm{K}$ ". Untuk mengurangi bias sampling, maka teknik pengelompokan sampel pada penelitian ini adalah dengan menggunakan random sampling.

Untuk pengambilan besar sampel dihitung berdasarkan rumus besar sampel:

$\mathrm{n}=$ (Steel and Torrie, 1980)

$\sigma^{2} \quad$ diambil dari studi yang sama sebelumnya atau maka diasumsikan $\sigma^{2} \approx \delta^{2}$, sehingga hasilnya :

$$
\begin{aligned}
\mathrm{n}= & (\mathrm{Z} 1 / 2 \alpha+Z \beta)^{2} \\
\mathrm{n}= & (1,645+0,842)^{2}=6,185 \text { dibulatkan } \\
& \text { menjadi } 6
\end{aligned}
$$

Minimal sampel tiap kelompok adalah 6 ekor tikus putih. Dalam penelitian ini kami menggunakan minimal 6 sampel untuk setiap kelompoknya, namun dikarenakan karena tingkat mortalitas sepsis cukup tinggi, pada kelompok yang dilakukan prosedur CLP yang bersifat invasif dan diketahui akan menimbulkan tingkat sepsis yang lebih berat (Menezes et al. 2008), Pada penelitian ini digunakan 10 sampel. CLP dilakukan setelah aklimatisasi 1 minggu.

Pemberian Choloroquine atau $\mathrm{NaCl} 0,9 \%$ dilakukan pada jam ke 24, 48, dan 72 sejak dilakukannya CLP. Sejak hari ke-1 sampai hari ke-5. Semua kelompok diberi diet standar. Setiap jumlah makanan yang dihabiskan, dan diperiksa akan tanda-tanda sepsis seperti hudling, inaktivitas, diare, dan piloereksi. Pemeriksaan survival rate dilakukan setiap 24 jam sejak dilakukannya CLP. Tikus yang menunjukkan tanda-tanda mendekati kematian (Moribund state), dikorbankan dan dicatat sebagai mortalitas. Pada hari ke 6 dilakukan pengambilan sampel darah (@2ml) dan kemudian semua tikus yang masih hidup dikorbankan. Perlakuan pada tikus mengikuti standar Humane end-point (ENV/JM/ MONO,2000)

Kadar $I L-1 \beta$ diperiksa dari plasma darah tikus. Sampel darah diambil melalui pembuluh darah sinus orbita dengan menggunakan pipet kaca dan diletakkan dalam tabung steril, lalu dibiarkan selama 2 jam pada suhu kamar kemudian disentrifugasi dengan kecepatan $1500 \mathrm{rpm}$ selama 15 menit. Plasma yang terpisah kemudian diambil dan dimasukkan ke dalam sumur-sumur pemeriksaan ELISA dengan menggunakan reagen IL-1 $\beta$ tikus (Thermo Fisher Scientific, USA).

Pengukuran aktivasi Caspase-1 dilakukan dengan cara Flowcytomery pada isolate Peripheral Blood Mono-Nuclear Cells (PBMC) dan Whole 
blood tikus percobaan. Reagen yang digunakan adalah FLICA 660 Caspase-1 Assay far-red fluorescence (Immunochemistry Technologies, USA) Aktivasi Caspase-1 kemudian diukur dengan bantuan alat Flowcytometry Fluorochrome detector 4.

Data disajikan dalam bentuk mean $\pm S D$ kemudian dianalisis menggunakan SPSS 22 for windows. Pemilihan analisis statistik dilakukan setelah dilakukan uji normalitas data dengan Shapiro-Wilk. Analisis statistik dilakukan dengan uji One Way ANOVA dan dilanjutkan dengan
Post Hoc Test Least Significant Difference/Fisher (LSD) menggunakan program SPSS for Windows release version 22. Post Hoc Test adalah uji hipotesis untuk membandingkan dua kelompok, yang dilakukan bila $p<0,05$. Uji One Way ANOVA adalah uji parametrik untuk membandingkan perbedaan mean pada lebih dari dua kelompok. Syarat uji One Way ANOVA adalah skala numerik, distribusi normal dan homogen. Apabila data tidak memenuhi syarat distribusi normal, maka digunakan uji alternatifnya yaitu uji KruskalWallis dilanjutkan dengan Mann -Whitney.

\section{HASIL DAN PEMBAHASAN}

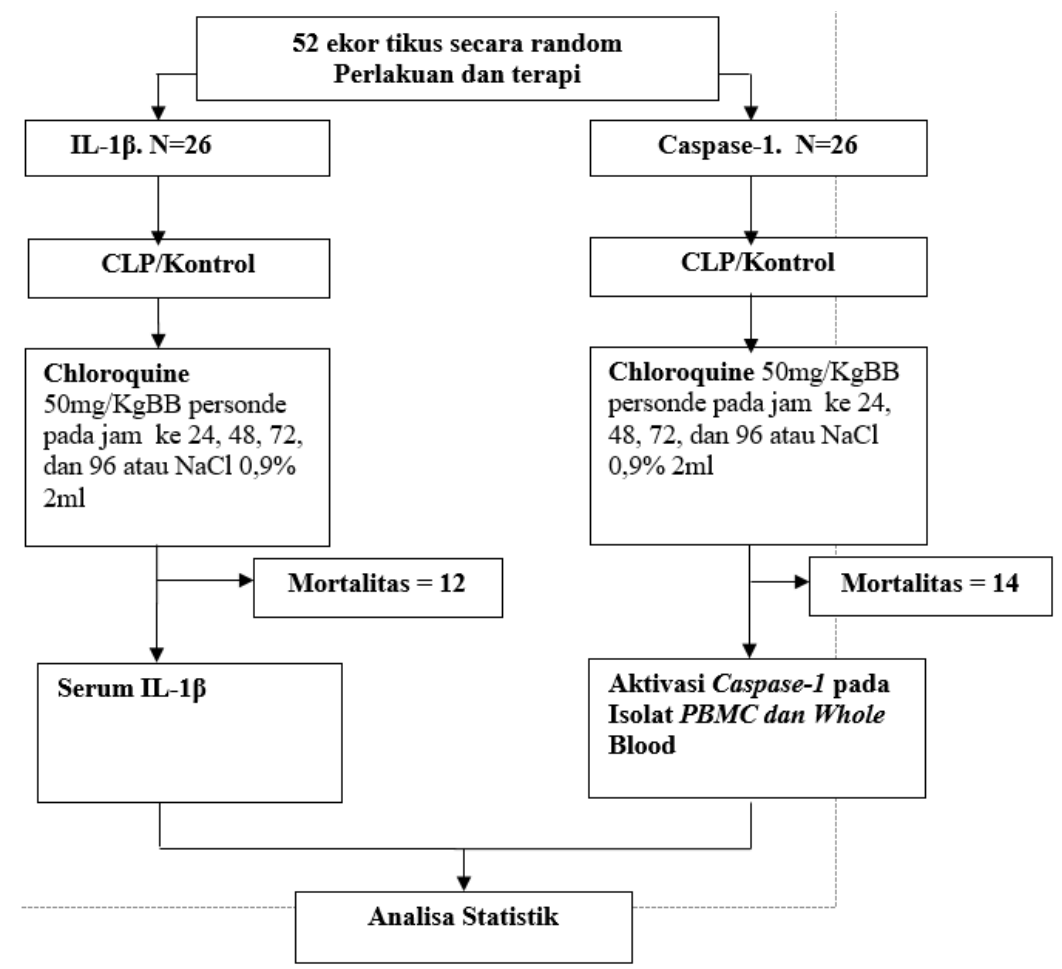

Gambar 1. Alur perjalanan penelitian dan mortalitas dari kelompok Il-1 $\beta$ dan kelompok aktivasi Caspase-1.

\section{Survival Rate}

Dari penelitian ini, kami dapatkan bahwa total tingkat mortalitas pada populasi eksperimen kami mencapai hingga 70\% dari semua kelompok yang disepsiskan. Tingkat mortalitas ini sebetulnya sesuai dengan yang dilaporkan oleh Menezes et al dan Toscano et al pada eksperimen yang menggunakan tikus C57BL/6 dan Balb/c (Menezes et al, 2008; Toscano et al, 2011).
Penelitian Menezes menyelidiki tingkat kematian dari tikus percobaan sepsis dengan menggunakan prosedur Cecal Ligation and Puncture (CLP). Didapatkan tingkat kematian yang cukup besar tergantung dari tinggi rendahnya derajat sepsis yang diinduksi. Berat ringannya derajat sepsis dapat ditentukan berdasar besar jarum yang digunakan untuk perforasi, dan letak ligasi sekum. 

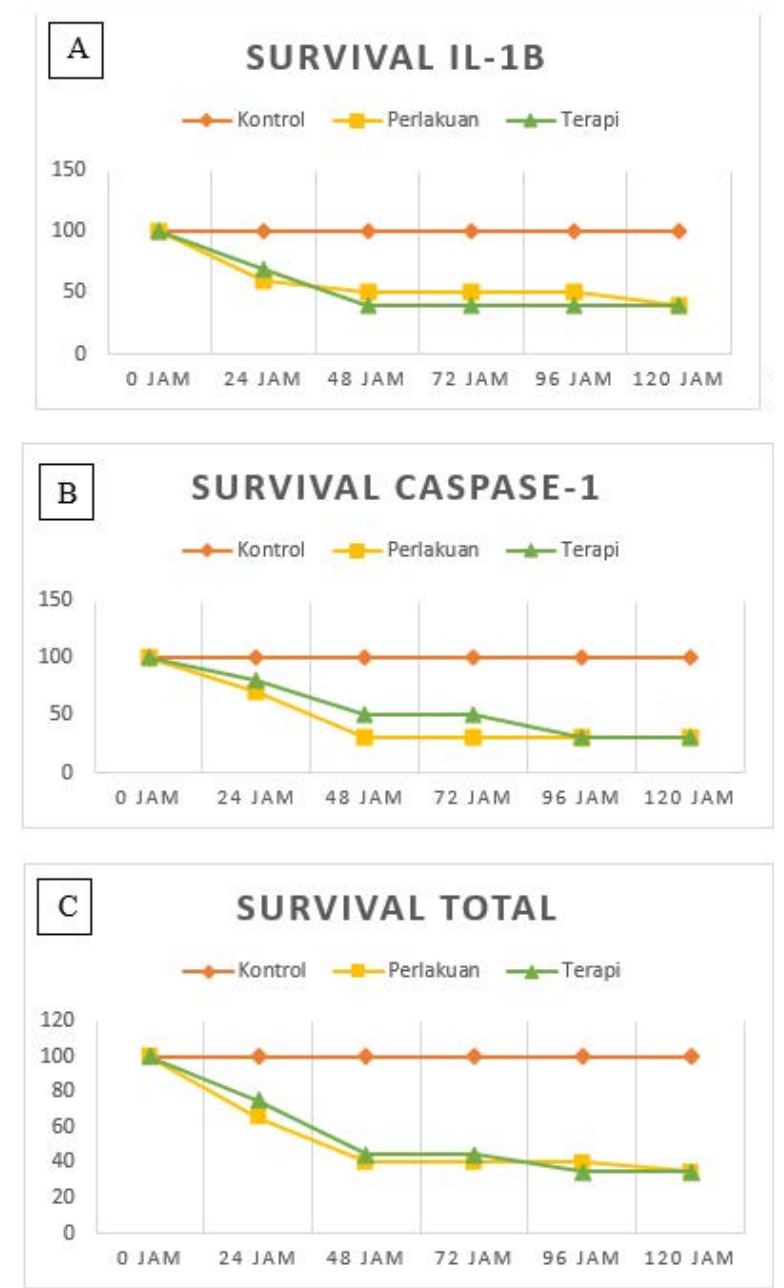

Gambar 2. Survival rate dari A) Kelompok IL-1 $\beta$, B) Kelompok Caspase-1, C) Kelompok IL-1 $\beta$ dan Caspase-1. Tidak didapatkan perbedaan bermakna antara sub-kelompok perlakuan dan terapi di kedua kelompok.

Pada penelitian ini, kami dengan sengaja mengiduksi sepsis berat dengan menggunakan metode perforasi sekum through and through dan letak ligasi $>1 \mathrm{~cm}$ di atas ujung distal sekum.
Survival Rate kelompok $I L-1 \beta$ dan Kelompok Caspase-1 tidak terjadi perbedaan yang bermakna antara sub-kelompok maupun antar kelompok.

Tabel 1. Survival rate antara kelompok dengan hasil analisa statistik

\begin{tabular}{ccccc}
\hline Kelompok & \multicolumn{2}{c}{ Survival rate hari 6 } & 95\% CI & P-Value \\
\hline & Perlakuan & Terapi & & \\
IL-1 $\beta$ & $40 \%$ & $40 \%$ & $(-27.4850)-21.7707$ & 0.810 \\
Caspase-1 & $30 \%$ & $30 \%$ & $(-8.3062)-0,4929$ & 0.073 \\
Total & $35 \%$ & $35 \%$ & & \\
\hline
\end{tabular}

Pada penelitian ini pemberian Chloroquine tidak berpengaruh secara signifikan dalam perbaikan survival rate pada tikus model sepsis. Bahkan pada kelompok $I L-1 \beta$ terdapat peningkatan angka mortalitas yang signifikan pada 24 jam pertama pemberian Chloroquine dengan dosis $50 \mathrm{mg} / \mathrm{KgBB}$, namun setelah itu tidak terdapat mortalitas tambahan sampai akhir penelitian. Pada kelompok aktivasi Caspase- 1 tetap tidak berbeda jauh dengan kelompok perlakuan, namun pada jam ke 72 dari pemberian CHQ dosis pertama terdapat mortalitas tambahan yang tidak terdapat pada kelompok perlakuan.

Efek pemberian CHQ pada hewan coba model sepsis pada penelitian-penelitian terdahulu menunjukkan adanya perbaikan survival rate 
yang bermakna dibandingkan kelompok kontrol (Yasuda et al, 2008; Yang et al, 2013,). Pada penelitian oleh Yang et al yang disepsiskan dengan CLP pada mencit $\mathrm{Balb} / \mathrm{C}$ dan kemudian diberikan injeksi intraperitoneal dosis tunggal CHQ 50mg/KgBB. Mencit lalu diinjeksi dengan LPS untuk menginduksi sepsis berat. Pada penelitan tersebut didapat tingkat survival yang lebih baik dibandingkan dengan kelompok mencit yang diberikan $\mathrm{NaCl}$ 0,9\% dan kelompok yang diberikan dosis CHQ $5 \mathrm{mg} / \mathrm{KgBB}$ (Yang et al, 2013). Hasil eksperimen di atas menunjukkan bahwa pemberian CHQ pada sepsis dapat mencegah terjadinya sepsis berat. Pada penelitian yang sama, Yang et al, 2013 juga melihat apakah pemberian CHQ setelah tejadinya sepsis berat dengan memberikan injeksi Chloroquine dengan dosis yang sama setelah injeksi LPS. CHQ diberikan sebanyak 4 kali pada jam ke 4, 12, 24 dan 36 setelah induksi LPS pada kelompok CHQ $50 \mathrm{mg} / \mathrm{KgBB}$. Pada eksperimen tersebut juga didapatkan hasil survival yang lebih baik. Hasil yang sama juga didapatkan pada eksperimen lain pada rangkaian penelitian yang sama di mana pemberian CHQ pada jam ke 24, 36, 48, 60 setelah terjadinya sepsis dapat melindungi mencit dari kematian pada percobaan dengan induksi sepsis dengan CLP tanpa tambahan injeksi LPS. Pada penelitian tersebut tidak menyertakan keterangan mengenai berapa lama sepsis terjadi setelah tindakan CLP dan jumlah kematian tikus setelah dilakukan CLP sebelum dilakukan injeksi LPS atau pemberian terapi. CLP merupakan model sepsis polimikrobial yang dianggap paling mendekati dengan sepsis pada manusia, walupun pada beberapa percobaaan induksi sepsis dengan CLP tingkat kematian cukup tinggi tergantung dari teknik yang dilakukan (Menezes et al, 2008). Tingkat kematian dapat mencapi 50-100\% dalam 48 jam pertama, yang mana sesuai dengan yang kami dapatkan pada penelitian ini. Survival rate pada penelitian Yang berkisar pada angka 60-70\% pada 60 jam pasca terapi. Akan tetapi, memang tidak kami dapatkan adanya perbedan survival rate yang bermakna antara kelompok tikus yang diinduksi sepsis, pada kelompok terapi dan non terapi.

Hasil penelitian oleh Yang et al tersebut mirip dengan penelitian oleh Yasuda et al yang menggunakan $\mathrm{CHQ}$ phosphate $50 \mathrm{mg} / \mathrm{Kg} \mathrm{BB}$ oral yang diberikan 6 jam pasca tindakan CLP. Survival rate pada penelitian ini juga menunjukkan hasil yang lebih baik pada kelompok yang diberikan CHQ secara oral. Akan tetapi, perlu diperhatikan bahwa pada mencit penelitian Yasuda et al, tingkat survival dalam 72 jam berada di angka $50 \%$, yang mana kurang lebih sama dengan hasil penelitian ini. Kekuatan penelitian Yang et al dan Yasuda et al adalah pengunaan jumlah mencit yang relative besar, yaitu Yang menggunakan 25 ekor mencit untuk tiap kelompok dan Yasuda menggunakan 13 ekor mencit untuk tiap kelompoknya.

Hasil penelitian Yang dan Yasuda berbeda dengan hasil penelitian oleh Takahashi et al, yang menggunakan CHQ $60 \mathrm{mg} / \mathrm{KgBB}$ pada $C 57 B L / 6 \mathrm{~N}$ mice dan GFP-LC3 transgenic mice. Takahashi meneliti bagaimana peran autofagi pada sepsis dan menggunakan CHQ sebagai inhibitor dari autofagi. Pada penelitian ini, hewan coba yang diberikan $\mathrm{CHQ}$ /inhibitor autofagi menunjukkan survival rate yang lebih buruk dibandingkan dengan tikus yang diberi normal saline (Takahashi et al , 2013).

Waktu pemberian dari CHQ dari masingmasing penelitian juga berbeda. Pada Yang, CHQ diberikan sebelum dan /atau 4 jam setelah sepsis berat, Yasuda memberikannya pada 6 jam setelah CLP, sedangkan Takahashi memberikannya 1 jam setelah CLP sedangkan pada penelitian ini CHQ diberikan 24 jam pasca CLP. Pada Hal ini menunjukkan bahwa peran CHQ pada sepsis masih memerlukan studi lebih mendalam, terutama yang perlu dipelajari terlebih dahulu adalah efek CHQ dari masing-masing spesies hewan coba dengan dosis optimum yang digunakan.

\section{Kadar $I L-1 \beta$}

Pemeriksaan kadar IL-1 plasma tikus merupakan rerata dari dua kali pengukuran untuk tiap sampelnya. Pada penelitian ini semua sampel diambil dari tikus yang bertahan hidup pada hari ke-6. Seperti yang diharapkan, didapatkan kadar yang lebih tinggi pada kelompok perlakuan CLP dengan placebo $\mathrm{NaCl}$ 0,9\% dibandingkan dengan kelompok CLP yang diberikan Chloroquine atau kelompok kontrol. Akan tetapi, setelah dianalisa dengan one-way ANOVA test, tidak didapatkan adanya perbedaan bermakna antar kelompok secara statistik. 
Tabel 2. Kadar IL-1 $\beta$ antara kelompok dengan hasil analisa statistik.

\begin{tabular}{cccc}
\hline & Rerata kadar IL-1; & $\mathbf{9 5 \%}$ CI & P Value \\
\hline Kontrol VS Perlakuan & 0.08700 vs 0.09680 & $(-0.02905)-0.00945$ & 0.547 \\
Kontrol VS Terapi & 0.08700 vs 0.08975 & $(-0.02327)-0.01777$ & 1.000 \\
Perlakuan VS Terapi & 0.09680 vs 0.08975 & $(-0.01427)-0.02837$ & 1.000 \\
\hline
\end{tabular}

KADAR IL-1 $\beta$

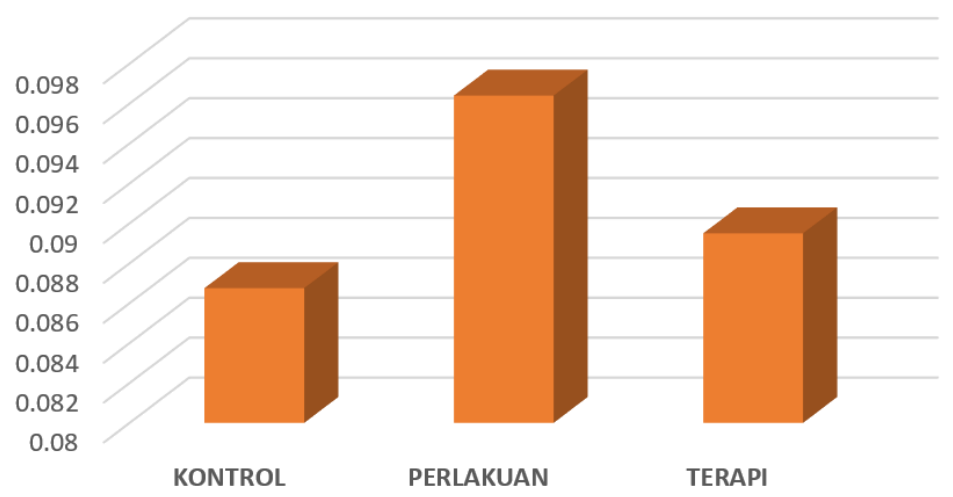

Gambar 3. Diagram batang yang menunjukkan rata-rata kadar IL-1 $\beta$ dari masing-masing sub-kelompok. Peningkatan tertinggi terdapat pada kelompok perlakuan, namun tidak bermakna secara statistik.

Pada penelitian ini, kami dapatkan terdapat penurunan kadar sitokin $I L-1 \beta$ pada kelompok sepsis yang diberi $\mathrm{CHQ}$ dibandingkan dengan kelompok yang diberi placebo. Perbedaann antar kelompok kecil tetapi sesuai dengan yang diarapkan. Kelompok kontrol tampak mempunyai rata-rata paling rendah dibandingkan dengan kelompok lain, di mana kelompok sepsis dengan placebo tampak mempunyai kadar paling tinggi.

CHQ, seperti yang telah banyak diteliti, mempunyai efek anti-inflamasi yang salah satunya dengan menurunkan kadar $I L-1 \beta$. Berbagai penelitian, baik berbasis hewan maupun manusia telah mengungkap mekanisme CHQ dapat menurunkan kadar $I L-1 \beta$. Pada prinsipnya, ada paling tidak 3 mekanisme dasar. Yang pertama adalah efek CHQ pada jalur $N F k B$ yaitu Contohnya pada penelitian oleh Jang et al, menunjukkan bahwa pemberian $\mathrm{CHQ}$ tidak menurunkan tingkat dari transkripsi dari $I L-1 \beta$, namun menurunkan kadar dari $m R N A I L-1 \beta$, yang mana mengisyaratkan adanya gangguan pada stabilitas dalam sel (diduga sebuah proses gangguan $\mathrm{PH}$ intrasel) sehingga menghambat ekspresi dan sekresi bentuk aktif dari $I L-1 \beta$. Mekanisme ke dua dari CHQ dalam menghambat produksi $I L$ $1 \beta$ adalah melalui penghambatan proses autofagi. Proses autofagi adalah proses kematian sel akibat degradasi dari komponen seluler yang terjadi pada vakuola autofagi (Fink et al 2005). Walaupun proses autofagi sendiri dianggap buka sebagai sebuah proses pro-inflamatori, namun beberapa penelitian lain telah menyatakan hubungan antara proses autofagi dengan produksi dari IL-1 $\beta$ (Yasuda et al, 2013).

\section{Aktivasi Caspase-1}

Aktivasi Caspase-1 diukur dengan cara Flowcytometry pada isolat Peripheral Mononuclear Cells (PBMC) dan Whole Blood (WB) dari tikus. Sampel darah diambil dari semua tikus yang bertahan hidup pada hari ke6. Sebelum pemeriksaan, dilakukan optimasi dengan menggunakan sampel darah tikus sehat untuk mennetukan Gating dan kompensasi serta menentukan kontrol positif dan negatif. Kontrol negatif menggunakan PBS dan kontrol positif menggunakan LPS 100ng/ml. 

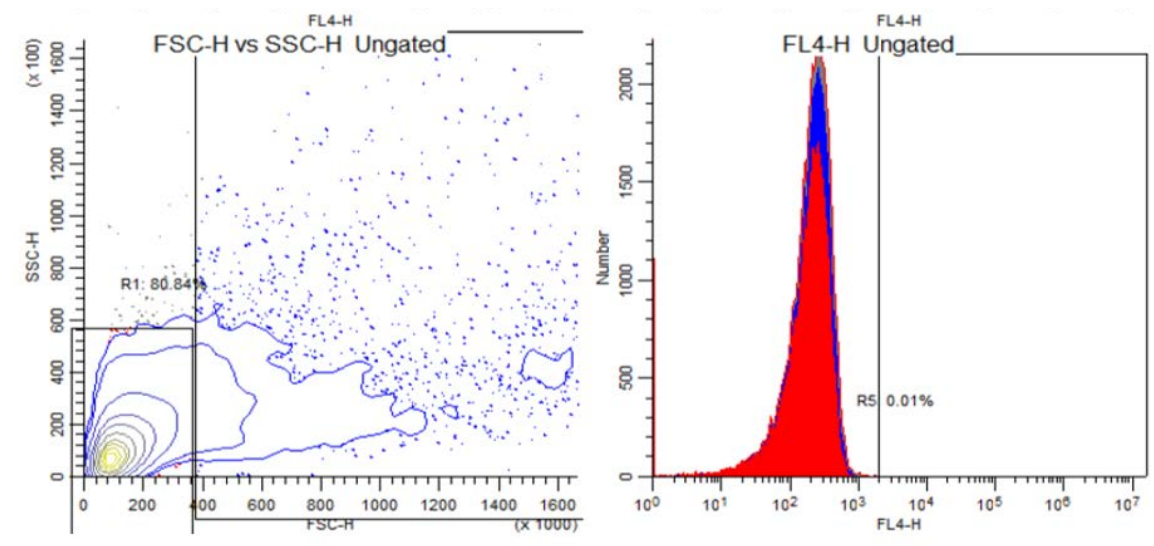

Gating dan PBMC unstained
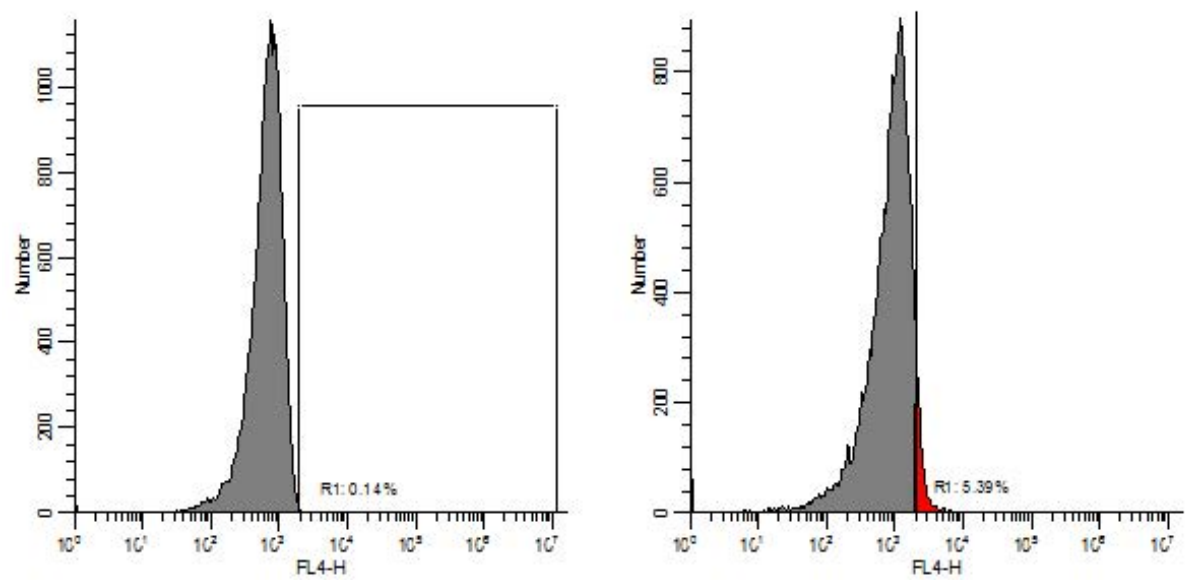

PBMC + PBS

PBMC + LPS
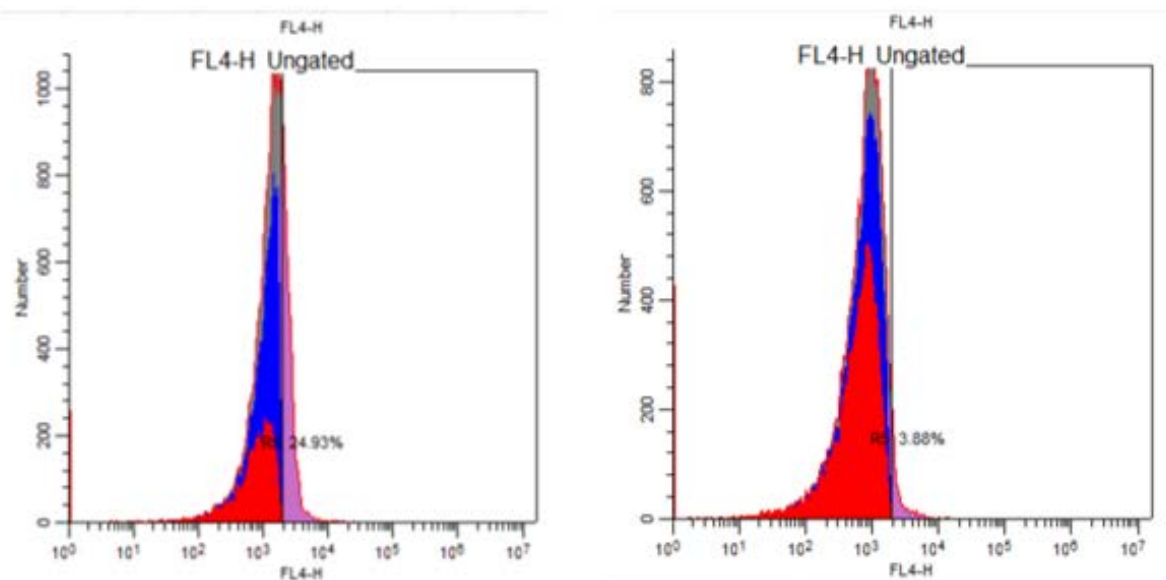

$\mathrm{CLP}+\mathrm{NaCl} 0,9 \%$

$\mathrm{CLP}+\mathrm{CHQ}$

Gambar 4. Gambar Scatter plot dan histogram Flowcytometry dari aktivasi Caspase-1 di PBMC. Cut off diambil dari kontrol negatif.

Pada penelitian ini, didapatkan peningkatan aktivasi dari pro-Caspase-1 menjadi Caspase-1 aktif secara rata-rata pada kelompok perlakuan baik pada PBMC maupun pada WB. Hal ini 

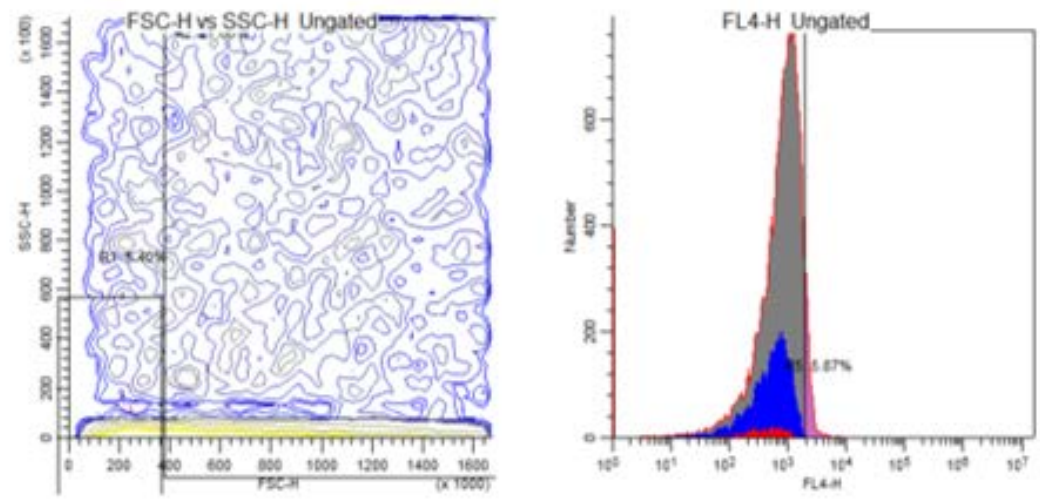

\section{Gating dan WB unstained}
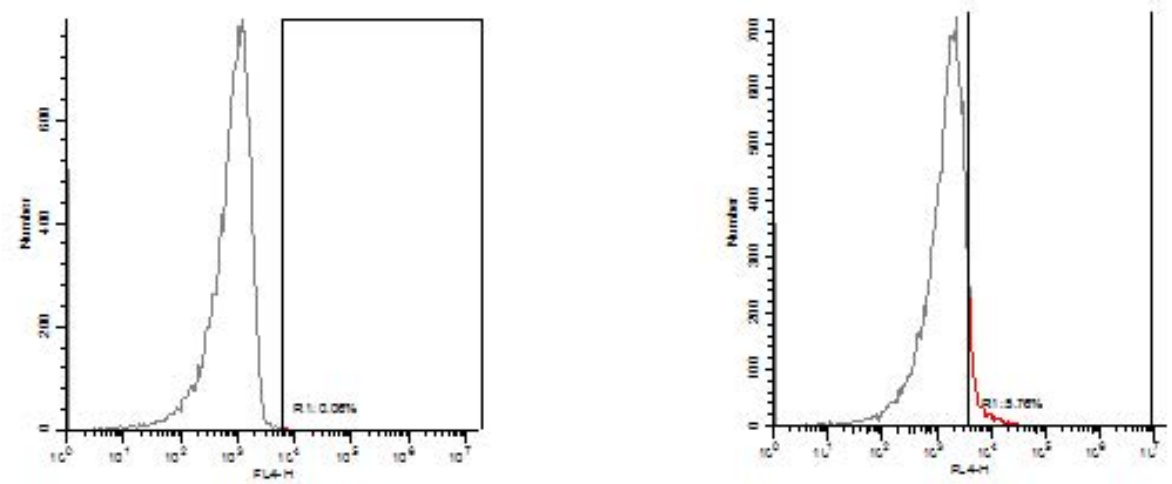

WB + PBS

WB + LPS
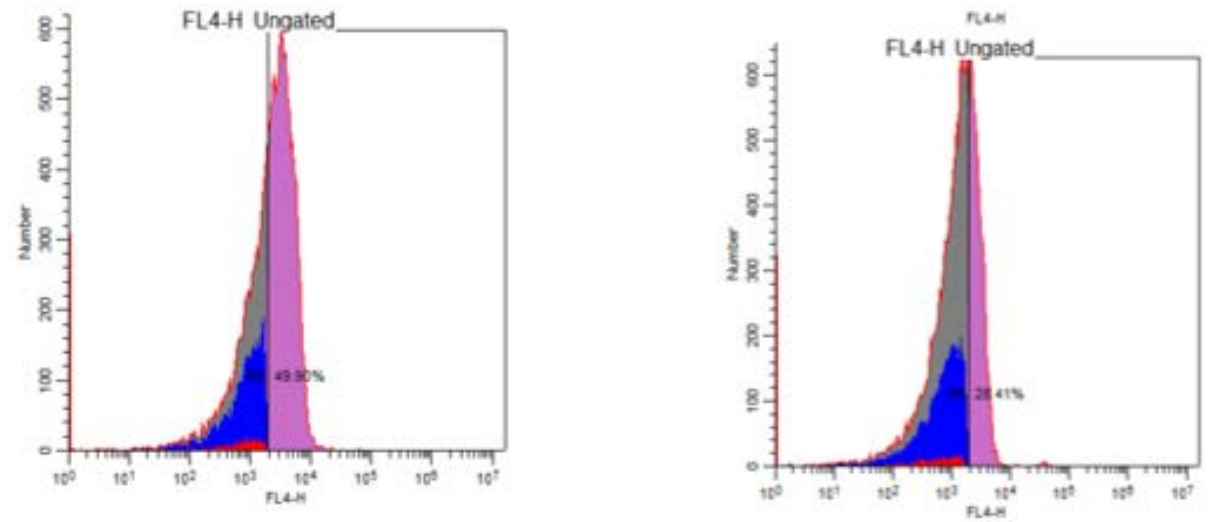

$\mathrm{CLP}+\mathrm{NaCl} 0,9 \%$

$\mathrm{CLP}+\mathrm{CHQ}$

Gambar 5. Gambar Scatter plot dan histogram Flowcytometry dari aktivasi Caspase-1 di Whole Blood. Cut off diambil dari kontrol negatif.

sesuai yang diharapkan dan mempunyai secara statistik dikarenakan kedua variabel korelasi dengan peningkatan kadar $I L-1 \beta$, diambil dari dua kelompok yang berbeda. walaupun korelasi tersebut tidak dapat dianalisa 
Tabel 3. Tingkat aktivasi Caspase- 1 antara kelompok dengan hasil analisa statistik

\begin{tabular}{cccccc}
\hline & Perlakuan & Terapi & Kontrol & $\mathbf{9 5 \%}$ CI & P-Value \\
\hline PBMC & $15.0367 \%$ & $9.463 \%$ & $14.44 \%$ & $(-6.72)-24.82$ & 0.856 \\
WB & $10.9933 \%$ & $2.993 \%$ & $6.0283 \%$ & $(-5.303)-5.844$ & 0.478 \\
\hline
\end{tabular}

Pada penelitian kami, hasil pengukuran aktivasi dari Caspase-1 menunjukkan hasil yang bervariasi antar sampel yang diperiksa. Kelompok perlakuan baik pada sampel isolat PBMC maupun WB menunjukkan peningkatan aktivasi dari Caspase-1. Peningkatan lebih tinggi dibandingkan dengan kelompok terapi, atau kelompok yang diberikan terapi CHQ. Hal ini seperti yang diharapkan dan sesuai dengan hipotesa kami.

Efek CHQ pada aktivasi Caspase-1 masih belum banyak diteliti. Hanya beberapa referensi yang didapatkkan. Kebanyakan penelitian yang telah dilakukan tidak secara spesifik melihat efek chloroquine pada aktivasi caspase-1 namun melihat efek CHQ pada inflammasome dan yang lebih banyak meneliti produk akhir dari aktivasi
Caspase-1, yaitu $I L-1 \beta$ (Shin et 2012, Shin et al 2013).

\section{SIMPULAN}

Pemberian CHQ menyebabkan penurunan kadar $I L-1 \beta$ dan aktivasi Caspase-1 secara ratarata namun tidak secara signifikan dalam analisa statistik. Sedangkan untuk survival rate tidak terbukti pemberian CHQ akan memberikan perlidungan dari kematian akibat sepsis. Hal tersebut meninjukkan bahwa mortalitas pada tikus model sepsis tidak semata-mata berhubungan dengan tingkat inflamasi. Penelitian lebih lanjut dengan metode yang lebih baik diperlukan untuk mengungkap misteri dari sepsis.

\section{DAFTAR PUSTAKA}

Bianchi ME. 2007, DAMPs, PAMPs and alarmins: all we need to know about danger. J. Leukoc. Biol. 81:1-5.

Bouernfeind F, Hornung V.2013, Of inflammasomes and pathogens-sensin of microbes by the inflammasome, EMBO Mol Med., 5(6):814-826

Dellinger RP, Levy MM, Rhodes A, Annane D, Gerlach H, Opal SM, et al.2013, Surviving Sepsis Campaign Guidelines Committee including the Pediatric Subgroup. Surviving sepsis campaign: international guidelines for management of severe sepsis and septic shock: 2012. Crit Care Med., 41:580- 637.

$\mathrm{ENV} / \mathrm{JM} / \mathrm{MONO}, 2000$, joint meeting of the chemicals committee and the working party on chemicals, pesticides and biotechnology. guidance document on the recognition, assessment, and use of clinical signs as humane endpoints for experimental animals used in safety evaluation. https:// ntp.niehs.nih.gov/iccvam/suppdocs/feddocs/oecd/oecd_gd19.pdf.

Fink SL \& Cookson BT. 2005, Apoptosis, Pyroptosis, and Necrosis: Mechanistic Description of Dead and Dying Eukaryotic Cells. Infection and immunity. 73 (4):1907-1916.

Hermawan AG. 2008, SIRS, Sepsis dan syok septik. $1^{\text {st }}$ edition. Surakarta: UNS press. Surakarta.

Hermawan AG. 2011 Steroid dosis rendah pada penatalaksanaan sepsis. $1^{\text {st }}$ edition. Surakarta: UNS press. Surakarta.

Kawai T \& Akira S. 2010, The role of pattern-recognition receptors in innate immunity: update on Tolllike receptors. Nat Immunol. 11:373-84.

Kawai T, Akira S. 2011, Toll-like Receptors and Their Crosstalk with Other Innate Receptors in Infection and Immunity. Immunity. 34: 637-650.

Lamkanfi M, Sarkar A, Walle LV, Vitari AC, Amer AO, Wewers MD, et al. 2010, InflammasomeDependent Release of the Alarmin HMGB1 in Endotoxemia. The J of Immun, 185: 4385-4392.

Menezes GB, Amaral SS, Alvarenga DM, Cara DC. 2008, Surgical procedures to an experimental polymicrobial sepsis: Cecal Ligation and Puncture. Braz J Vet Pathol, 1(2): 77 - 80 
Opal SM, Garber GE, LaRosa SP, et al. 2003, Systemic host responses in severe sepsis analyzed by causative microorganism and treatment effects of drotrecogin alfa (activated). Clin Infect Dis. $37: 50-58$.

Shin MS, Kang Y, Lee N, Wahl ER, Kim SH,Kang KS, Lazova R, Kang I.2013, Self dsDNA induces IL-1 $\beta$ production from human monocytes by activating NLRP3 inflammasome in the presence of anti-dsDNA antibodies. J Immunol. 15; 190(4): 1407-141.

Shin MS, Kang Y, Lee N, Kim SH, Kang KS, Lazova R, Kang I. 2012, U1-snRNP activates the NLRP3 inflammasome in human Monocytes. J Immunol. 15; 188(10): 4769-4775.

Takahashi W, Watanabe E, Fujimura L, Watanabe-Takano H, Yoshidome H4, Swanson PE, et al. 2013. Kinetics and protective role of autophagy in a mouse cecal ligation and punctureinduced sepsis. Critical Care, 17:R160.

Toscano MG, Ganea D, Gamero AM. 2011, Cecal Ligation Puncture Procedure. J Vis Exp. 7(51): 2860. Van der Poll T \& Opal SM. 2008, Host-pathogen interactions in sepsis. Lancet Infect Dis. 8:32-43.

Wen H, Miao EA, Ting JPY. 2013, Mechanisms of NOD-like Receptor-Associated Inflammasome Activation. Immunit, 39: 432-441.

Yang M, Cao L, Xie M, Yu Y, Kang R, Yang L, et al. 2013, Chloroquine Inhibits HMGB1 Inflammatory Signaling and Protects Mice from Lethal Sepsis. Biochem Pharmacol. 86(3): 410-418.

Yasuda H, Leelahavanichkul A, Tsunoda S, Dear JW, Takahashi Y, Ito S, Hu X, Zhou H, Doi K, Childs R, Klinman DM, Yuen PST, Star RA. 2008, Chloroquine and inhibition of Tolllike receptor 9 protect from sepsis-induced acute kidney injury. Am J Physiol Renal Physiol. 294(5): F1050-F1058.

Zainuddin M. 1999, Metodologi Penelitian. Lembaga Penelitian Universitas Airlangga, Surabaya. 